\title{
Morphological Investigation of the Brain of the African Ostrich (Struthio camelus)
}

\author{
Investigación Morfológica del Cerebro de la Avestruz Africana (Struthio camelus)
}

\author{
Ashraf A. Karkoura*; Mohamed A. M. Alsafy*; Samir A. A. Elgendy* \& Fatima A. Eldefrawy*
}

KARKOURA, A. A.; ALSAFY, M. A. M.; ELGENDY, S. A. A. \& ELDEFRAWY, F. A. Morphological investigation of the brain of the African ostrich (Struthio camelus). Int. J. Morphol., 33(4):1468-1475, 2015.

SUMMARY: The aim of the current study focused on the morphological features of the brain of the African ostrich. The brain was studied macroscopically, microscopically and the measurements of all brain parts were demonstrated. The brain of ostrich was rhombus in shape with large obtuse triangular cerebrum with sagittal dorsomedial wulst. The olfactory bulb was small with undeveloped olfactory lobe. The diencephalon gave rise to the pineal gland, which was inverted tubal structure with an obtuse triangle bottom. Large optic chiasm and optic tract demonstrated that continued to the optic lobes. The cerebellum was represented by central vermis that had numerous transverse fissures and two small lateral floccules on its lateral surface. The medulla oblongata with clear pontine flexure and no obvious pons or trapezoid body appeared. The histological results revealed that the cerebral cortex formed of several ill-defined layers of neurons. The most common appearance characterized by few small neurons supported by neuroglia. The cerebellar cortex consists of three layers namely molecular layer, Purkinje cells layer and internal granular layer, the layer of Purkinje cells characterized by a very large cell body. The medulla oblongata was covered by pia mater of loose connective tissue that covered with simple squamous epithelium and vascular supply extended beneath the pia mater. The cell nuclei of the medulla oblongata were formed from few multipolar neurons, supported by few neuroglia. The fourth ventricle was lined by pseudo stratified columnar ciliated ependymal cells.

KEY WORDS: Brain; Morphology; Ostrich.

\section{INTRODUCTION}

The African ostrich is native to Africa and Arabian Desert areas. They mainly live in dry African regions and the extremely hot Arabian Desert, in harsh climates with food shortages (Mushi et al., 1998). However, in the last 2 decades, people have begun to pay more attention to ostriches because of their great economic value. The ostrich breeding industry is growing rapidly in many places, including the USA, Australia, New Zealand, Israel, Canada, Europe, and China (Al-Nasser et al., 2003). Hence, ostrich breeding is improving greatly recently, and researches about ostrich is picking up. There are some reports about the external features of the African ostrich brain (Wengin et al., 2005; Peng et $a l ., 2010)$ but there are not any literatures about the internal features and the histological structures of the brain parts. The avian cerebral cortex consists of two materials, gray matter, and white matter, the gray matter situated externally while the white matter situated internally (Dellman \& Meclure, 1975). The cerebral cortex is composed of sex layers, molecular layer, external granular layer, external pyramidal layer, internal granular layer, internal pyramidal layer, and multiform layer (Pal et al., 2003).
Therefore, the aim of this study was to make a spotlight on the gross anatomy, brain parts dimensions, and the histological structures of the brain of the African ostrich.

\section{MATERIAL AND METHOD}

Ten fresh heads of ostriches of both sexes aged 9-12 month collected from the slaughterhouse of Alexandria and Behera governorate in Egypt were used in the current study.

One ostrich head was opened freshly to get the samples for histological examination, about $1 \mathrm{~cm}^{3}$ Samples from cerebrum, cerebellum, and Medulla oblongata were fixed in $10 \%$ phosphate buffered formaldehyde. The fixed specimens were processed for paraffin sections. Four $\mu \mathrm{m}$ thick serial sections were prepared and stained using Mayer's hematoxylin and eosin (H\&E) stain. 
The other heads were kept in freezer for the morphological study. One head were sagittaly sectioned and the other heads; the skulls were opened and the brain with its meninges was removed outside the cranium. The length and width $(\mathrm{mm})$ of every part of the brain was measured using Vernier caliper. All values were expressed as means \pm SEM. The data were analyzed using general linear model of SAS (SAS Institute Inc., 1992) as shown in Table I.

Table I. The dimensions of the brain parts of the African ostrich.

\begin{tabular}{lcc}
\hline \multirow{2}{*}{ Items } & Length $(\mathbf{m m})$ & Width $(\mathbf{m m})$ \\
\cline { 2 - 3 } & $\mathbf{( M e a n} \pm \mathbf{S E})$ & $\mathbf{( M e a n} \pm \mathbf{S E})$ \\
\hline Total brain & $58.48 \pm 0.44 \mathrm{a}$ & $42.63 \pm 0.63 \mathrm{~b}$ \\
Wulst & $28.75 \pm 0.32 \mathrm{a}$ & $10.88 \pm 0.43 \mathrm{~b}$ \\
Cerebral hemisphere & $31.88 \pm 0.43 \mathrm{a}$ & $20.50 \pm 0.46 \mathrm{~b}$ \\
Olfactory lobe & $15.15 \pm 0.67 \mathrm{a}$ & $8.75 \pm 0.32^{\mathrm{b}}$ \\
Optic lobe & $16.38 \pm 0.43 \mathrm{a}$ & $8.48 \pm 0.48^{\mathrm{b}}$ \\
Pineal body & $6.93 \pm 0.22^{\mathrm{a}}$ & $6.40 \pm 0.22^{\mathrm{a}}$ \\
Cerebellum & $26.75 \pm 0.32^{\mathrm{a}}$ & $18.70 \pm 0.34 \mathrm{~b}$ \\
Medulla oblongata & $18.85 \pm 0.43 \mathrm{a}$ & $12.78 \pm 0.34 \mathrm{~b}$ \\
Hypophysis & $8.23 \pm 0.34^{\mathrm{a}}$ & $9.13 \pm 0.43^{\mathrm{a}}$ \\
Optic tract & $7.98 \pm 0.21^{\mathrm{a}}$ & $3.35 \pm 0.25^{\mathrm{b}}$ \\
Infundibulum & $4.25 \pm 0.32^{\mathrm{a}}$ & $3.48 \pm 0.21^{\mathrm{a}}$ \\
\hline
\end{tabular}

\section{RESULTS}

Gross anatomy of the brain. The brain of ostrich was rhombus in shape. The wide rostral angle was formed by the rostral part of cerebrum. While the caudal narrow angle was formed by the cerebellum and Medulla oblongata. The adult brain divided into three main parts: the hind brain (Medulla oblongata, Cerebellum), the midbrain (Peduncles of the cerebrum, Optic lobes), and the forebrain (Thalamus, Pineal body, Hypophysis, Optic tracts and chiasm, Cerebral hemispheres, Olfactory lobes)

The structures that appeared on the dorsal aspect of the brain were the olfactory bulbs, cerebral hemispheres, optic lobe, pineal body, cerebellum, and Medulla oblongata. Whatever the structures that appeared on the lateral aspect of the brain were the olfactory bulb, cerebrum, cerebellum, Medulla oblongata, optic lobe, optic chiasm, optic tracts, and hypophysis. While the structures that appeared on the ventral aspect of the brain were the sagittal eminence, olfactory lobes, hypothalamus, optic lobes, optic chiasm, optic tracts, hypophysis and Medulla oblongata.

Cerebrum. The cerebrum was the largest part of whole brain; it covered completely the diencephalon and largely the midbrain (Figs. 1-6A). It formed the dorsal portion that extended from the olfactory bulb rostrally to the cerebellum caudally. It was convex dorsally and broad caudally with

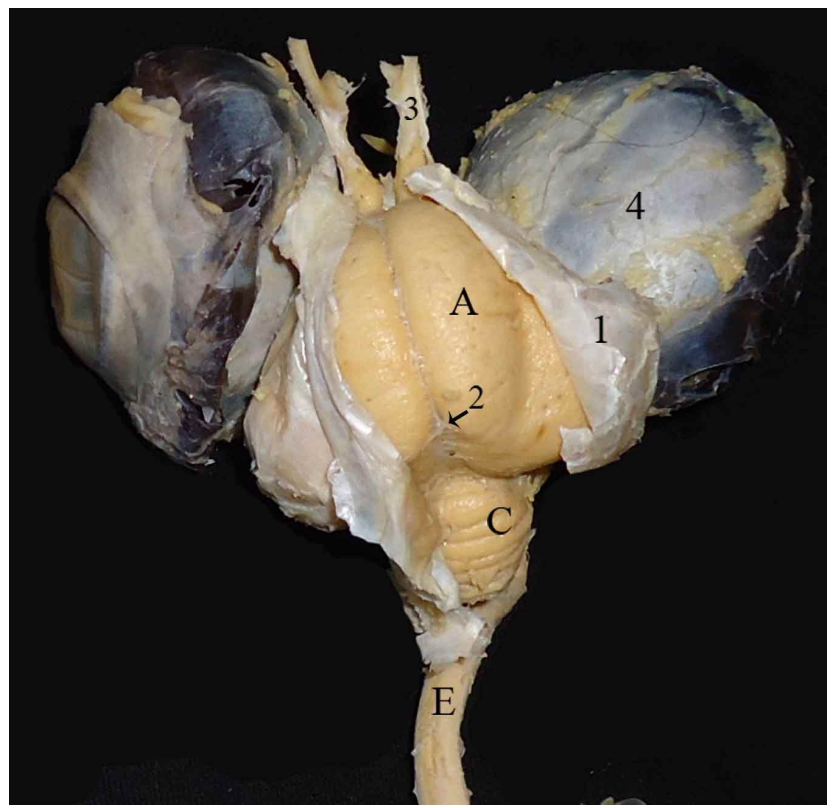

Fig.1. Dorsal view of the brain of ostrich with meninges, two eyes and spinal cord: $\mathrm{A}=$ cerebrum, $\mathrm{C}=$ cerebellum, $\mathrm{E}-$ spinal cord, $1=$ dura matter, $2=$ Arachnoid, $3=$ olfactory nerve, $4=$ eye.

two rounded wide angles. The average length and width of the cerebral hemisphere were $31.88 \mathrm{~mm}$ and $20.50 \mathrm{~mm}$ respectively. The two cerebral hemispheres were separated by the dorsal median longitudinal fissure. On each side of the median longitudinal fissure, the sagittal eminence (wulst) viewed as a sagittal dorsomedial swelling, which extended from the olfactory bulb to the caudal pole of the hemispheres (Fig. 3 (2) and Fig. 4 (1)). The wulst length and width were

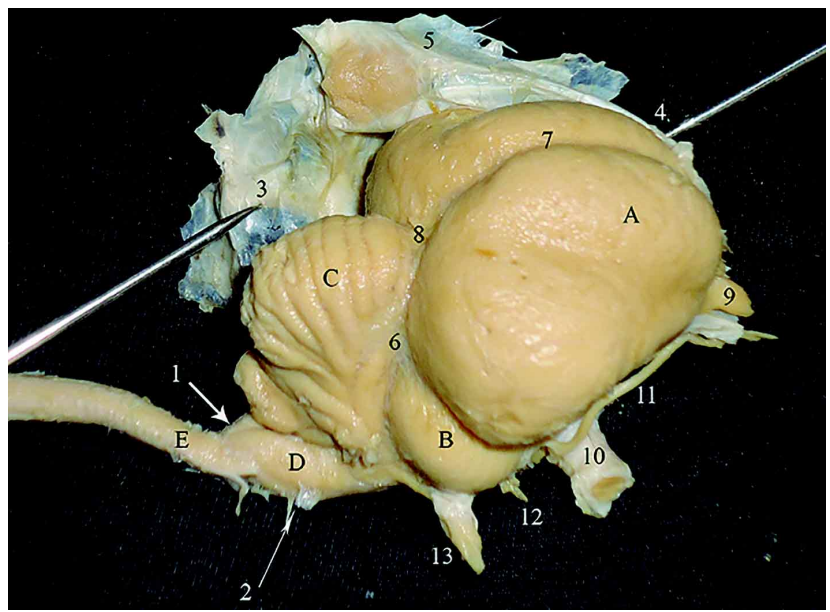

Fig. 2. Dorsolateral view to the brain with meninges: $\mathrm{A}=$ cerebrum, $\mathrm{B}=$ optic lobe, $\mathrm{C}=$ cerebellum, $\mathrm{D}=$ medulla oblongata, $\mathrm{E}=$ spinal cord, $1=$ nuchal flexure, $2=$ abducent nerve., $3=$ tentorum cerebelli, $4=$ falex cerebri, $5=$ dura matter, $6=$ arachnoid, $7=$ dorsal cerebral longitudinal fissure, $8=$ dorsal transverse fissure, $9=$ olfactory nerve, $10=$ optic nerve, $11=$ trochlear nerve, $12=$ oculomotor, $13=$ trigeminal nerve. 
$28.75 \mathrm{~mm}$ and $10.88 \mathrm{~mm}$. The wulst surrounded and separated from the cerebral hemisphere laterally by a curved shallow groove telencephalic vallecula (Fig. 3 (1) and Fig. 4 (2)). The cerebral surface was smooth, and there were no gyri or sulci. The transverse fissure separated the caudal pole of the cerebral hemispheres from the cerebellum dorsally and extended to separate the optic lobe laterally and ventrally (Fig. 2 (8), Fig. 3 (7) and Fig. 4 (6)). The central parts of the transverse fissure deepen to form triangular fossa occupied by the pineal body. Meanwhile the tip of the rostral pole

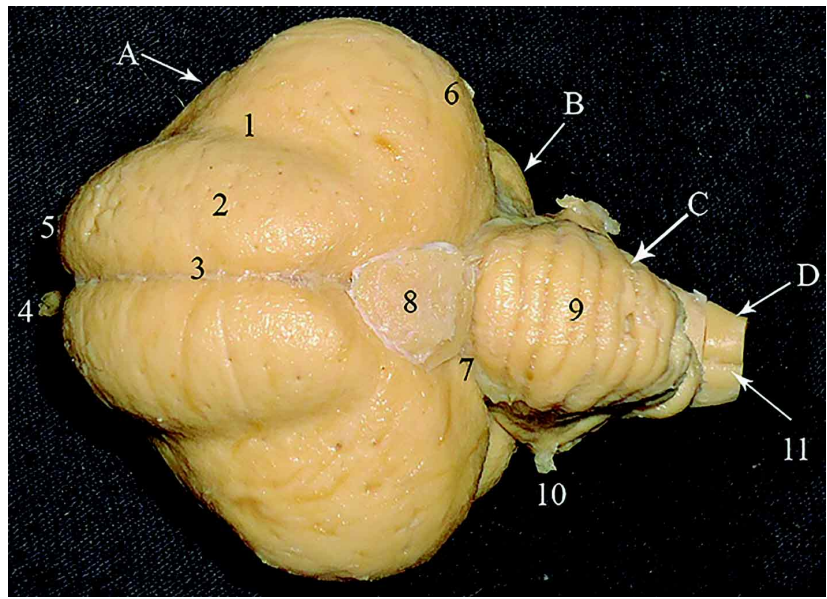

Fig. 3. Dorsal view of the brain: $\mathrm{A}=$ cerebrum, $\mathrm{B}=$ optic lobe, $\mathrm{C}=$ cerebellum, $\mathrm{D}=$ medulla oblongata, $1=$ vallecula, $2=$ wulst, $3=$ dorsal cerebral longitudinal fissure, $4=$ olfactory nerve, $5=$ rostral cerebral pole, $6=$ caudal cerebral pole, $7=$ dorsal transverse fissure, $8=$ pineal body, $9=$ cerebellar vermis, $10=$ cerebellar auricle, $11=$ dorsal medullary fissure.

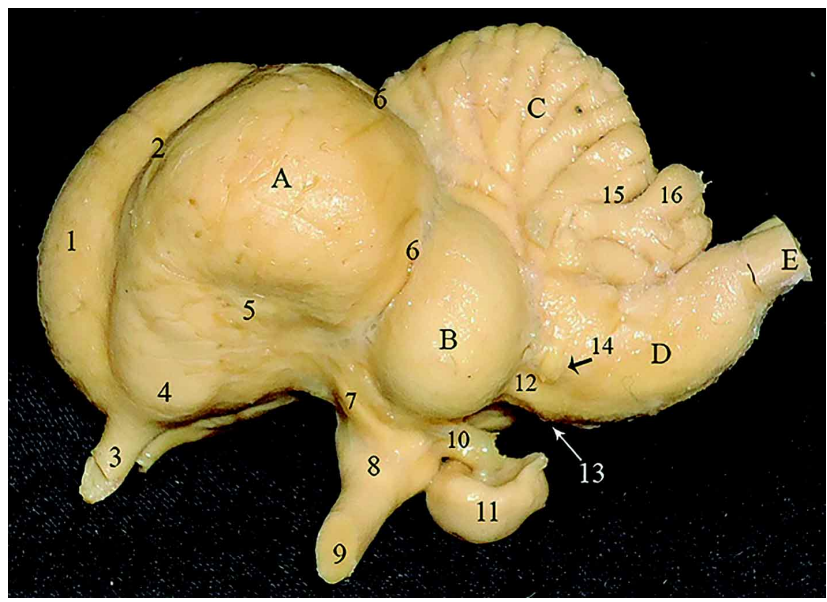

Fig. 4. Lateral view of the brain: $\mathrm{A}=$ cerebrum, $\mathrm{B}=$ optic lobe, $\mathrm{C}=$ cerebellum, $\mathrm{D}=$ medulla oblongata, $\mathrm{E}=$ spinal cord, $1=$ wulst, $2=$ vallecula, $3=$ olfactory nerve, $4=$ olfactory lobe, $5=$ orbital print, $6=$ lateral part of transverse fissure, $7=$ optic tract, $8=$ optic chiasm, $9=$ optic nerve, $10=$ infundibulum, $11=$ hypothysis, $12=$ midbrain, $13=$ pons, $14=$ trigeminal nerve, $15=$ cerebellar fissures, $16=$ cerebellar lobe. gave access to the small olfactory bulb. Consequently, to the narrowness of the rostral pole, it inserted between the two large orbits that leave a great print (impression bulbi oculi) in the ventrolateral (orbital) surface of the hemispheres. The orbital surface of the brain composed from the cerebral hemispheres dorsally and the rostral part of the optic lobe and the rostral surface of the optic tracts. In the ventral surface of the cerebral hemisphere, there were ventral median cerebral fissure (Fig. 5 (5)); it considered the ventral extension of the dorsal longitudinal cerebral fissure (Fig. 2 (7) and Fig. 3 (3)), this fissure interrupted by the optic chiasm. Beside this fissure, there were two-paramedian protuberances (Fig. 5 (4)). The optic lobe covered up the ventral part of the caudal pole of the hemispheres. Each hemisphere contained a large lateral ventricle.

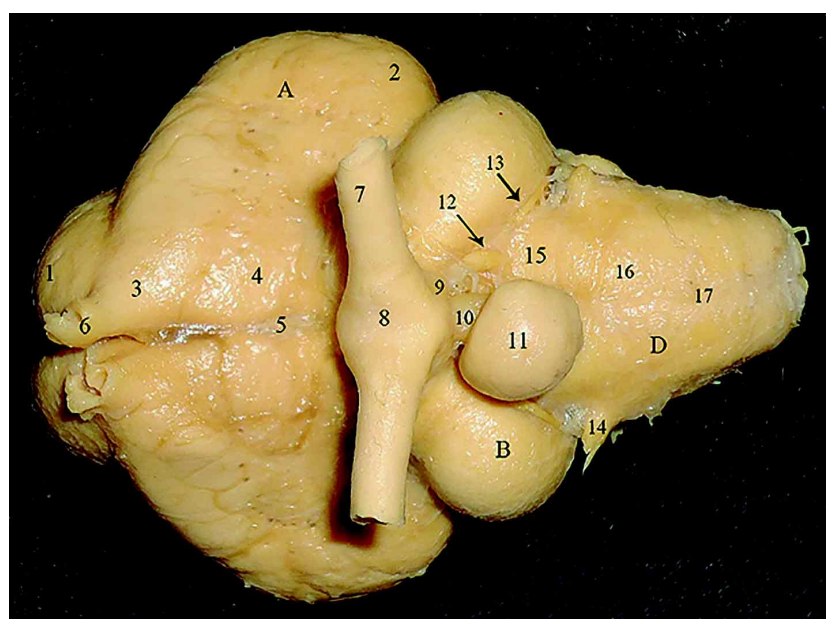

Fig. 5. Ventral view of the brain: $\mathrm{A}=$ cerebrum, $\mathrm{B}=$ optic lobe, $\mathrm{D}=$ medulla oblongata $1=$ rostral cerebral pole, $2=$ caudal cerebral pole, $3=$ olfactory lobe, $4=$ paramedian eminence, $5=$ ventral longitudinal fissure, $6=$ olfactory nerve, $7=$ optic nerve, $8=$ optic chiasm, $9=$ optic tracts, 10= infundibulum, 11= hypophysis, 12= oculomotor nerve, $13=$ trochlear nerve, $14=$ trigeminal nerve, $15=$ midbrain $16=$ pons, $17=$ ventral medullary fissure.

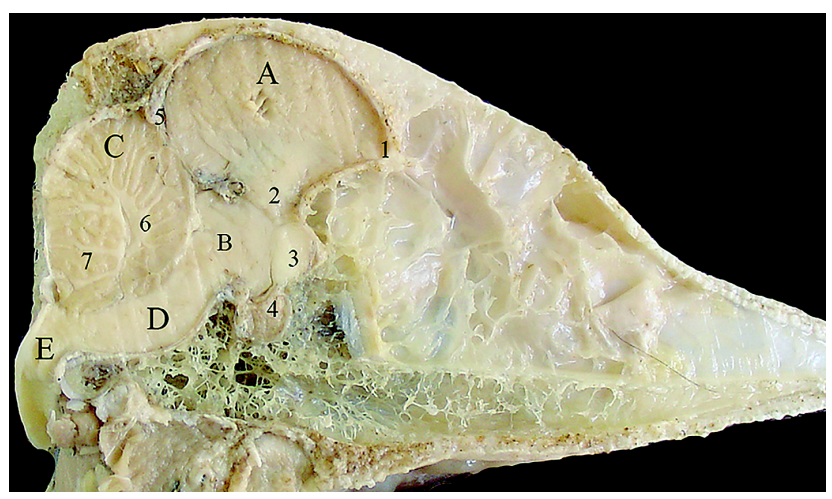

Fig. 6. Sagittal section of the head: $\mathrm{A}=$ cerebrum, $\mathrm{C}=$ cerebellum, $\mathrm{D}=$ medulla oblongata, $\mathrm{E}=$ spinal cord, $1=$ olfactory nerve, $2=$ thalamus, $3=$ optic chiasm, $4=$ hypophysis, $5=$ pineal gland, $6=$ cerebellar medulla, $7=$ cerebellar lobe . 
Olfactory bulbs. Small olfactory nerve and bulb appeared at the rostral pole of the cerebral hemispheres; however, there was undeveloped olfactory lobe in the ventral surface of the rostral pole of the cerebral hemispheres (Fig. 4 (4) and Fig. 5 (3)), the olfactory lobe measured about $15.15 \mathrm{~mm}$ length and $8.75 \mathrm{~mm}$ width. There were not olfactory tracts like that of the mammals.

Diencephalon. It located in the base of the brain between the telencephalon and midbrain covered by the cerebral hemispheres dorsally; the diencephalon included the Thalamus, hypothalamus, and epithalamus (pineal body). The third ventricle passed in the diencephalon and communicated the lateral ventricle through the interventricular foramen.

Optic tracts and optic chiasm. The ventral surface of the brain showed little demarcation between the structures. The optic tracts and optic chiasm in the ventral surface of the brain appeared clear and large. The optic tract derived from the optic lobe measured about $7.93 \mathrm{~mm}$ in length and 3.35 $\mathrm{mm}$ in width and located at the rostral part of it (Fig. 4 (7) and Fig. 5 (9)). The optic tract had two faces anterior and posterior. The optic chiasm indicated the crossing of the right and left tracts to emerge the optic nerves to the eyeballs (Figs. 4-5 (8)). The optic chiasm and the optic nerves situated on the diencephalons region.

Pineal body. The pineal body appeared inverted tubal structure with an obtuse triangle bottom about $6.93 \mathrm{~mm}$ in length and $6.40 \mathrm{~mm}$ in width, it originated from diencephalon the tubal part is pass between the cerebrum and cerebellum, it bottom settle in the central part of the transverse fissure (Fig. 3 (8)). Pineal considered the line of demarcation between midbrain and diencephalon. The dorsal part of the pineal body tightly attached to the dura matter.

Hypophysis. The hypophysis appeared a large globular shape structure (Figs. 4-5 (11)) measured $8.23 \mathrm{~mm}$ in length and $9.13 \mathrm{~mm}$ in width. It suspended from the ventral surface of the brain by the infundibulum that was about $4.25 \mathrm{~mm}$ in length and $3.48 \mathrm{~mm}$ in width, which defined as hallow tube like structure connect hypothalamus with hypophysis, the hypophysis is related to the diencephalon region ventrally at the level of optic lobe.

Thalamus. Two rounded structures appeared beneath the two cerebral hemispheres rostral to the origin of the pineal body.

Midbrain. Midbrain was small narrow area the unique structure related to this region is the optic lobe which considered the analogues to the rostral colliculus of tectum (Fig. 4 (12) and Fig. 5 (15)). Midbrain presented caudal to the diencephalon definitely to the hypothalamus and hypophysis and no line of demarcation between them (diencephalon and mesencephalon). Midbrain fused caudally with the pons. The area between the two lobes (interlobar midbrain) was obscured dorsally by the caudal pole of cerebrum and the cerebellum. The ventral part considered the cerebral peduncles (crus) with intercrural fossa. The $3^{\text {rd }}$ and $4^{\text {th }}$ cranial nerves originated from the midbrain ventral aspect. In addition, themesencephalon aqueduct passes through the midbrain, which connects, between the 3rd and 4 th ventricles.

Optic lobe. It originated from the midbrain (Figs. 2-5B), it was about $16.38 \mathrm{~mm}$ in length and $8.48 \mathrm{~mm}$ in width, It extended dorsally between the caudal pole of cerebral hemisphere rostrally and cerebellum caudally, meanwhile ventrally extended between the optic tract and cerebral hemispheres rostrally and the cerebral peduncles and pons caudally. It appeared as a bulge laterally, it gave rise to the optic tracts.

Cerebellum. The cerebellum was long diamond shape (Fig. 2-4C) measured about $26.75 \mathrm{~mm}$ in length and $18.70 \mathrm{~mm}$ in width. It extended from the transverse fissure and the fourth ventricle, it laid upon the Medulla oblongata. The rostral apex of cerebellum fit with the central fossa of the transverse fissure. The cerebellum was large when compare to the total size of the brain and compressed laterally. It represented by central convex vermis with numerous transverse fissures with small ventrolateral cerebellar auricles the so-called flocculus. The cerebellum divided by 9 primary fissures to 10 lobes which subdivided by 7 secondary fissures to 14 lobules (folia). In the sagittal section, the cerebellar cortex (gray matter) arranged externally with the cerebellar medulla (white matter). As the cerebellum covered the 4th ventricle, it includes the cerebellar recess ventral to the base of the cerebellum.

Medulla oblongata. It was a club shaped structure (Figs. 25D) measured $18.85 \mathrm{~mm}$ in length and $12.78 \mathrm{~mm}$ in width, the most caudal part of the brain followed by the spinal cord. in the dorsal surface medulla form slight dorsal convexity with the spinal cord the nuchal flexure, and has the rhomboid fossa to form the floor of the fourth ventricle, at the caudal angle of the fossa present the dorsal median medullary fissure. In the ventral surface Medulla oblongata with the pons formed the great ventral convexity the pontine flexure, and has the ventral medullary fissure is wider but shallow than the dorsal fissure. It lacks from the trapezoid body pyramid and its decussation. At the rostral end of medulla, present the pons (Fig. 5 (16)) that is not prominent and represented by flat area. The medulla gives the origin to cranial nerves from $5^{\text {th }}$ to $12^{\text {th }}$ cranial nerves. 


\section{Microscopical investigation of the brain}

Cerebrum: The cerebral cortex was formed of several neurons, which were ill defined. The most common appearance characterized by few small neurons (arrows) supported by neuroglia (Fig. 7). The 3rd ventricle lined with simple layer of cuboidal ependymal cells (Fig. 8).

Cerebellum: The cerebellum characterized by many small folds, each fold is supported at its center by cerebellar medulla which was formed from several axons. This layer was surrounded by granular layer of densely packed very small spherical neurons. An outer layer called molecular layer surround the granular layer and formed of scattered small neurons. Between these two layers, there was a single layer of Purkinje cells, which were characterized by a very large cell body (Fig. 9).

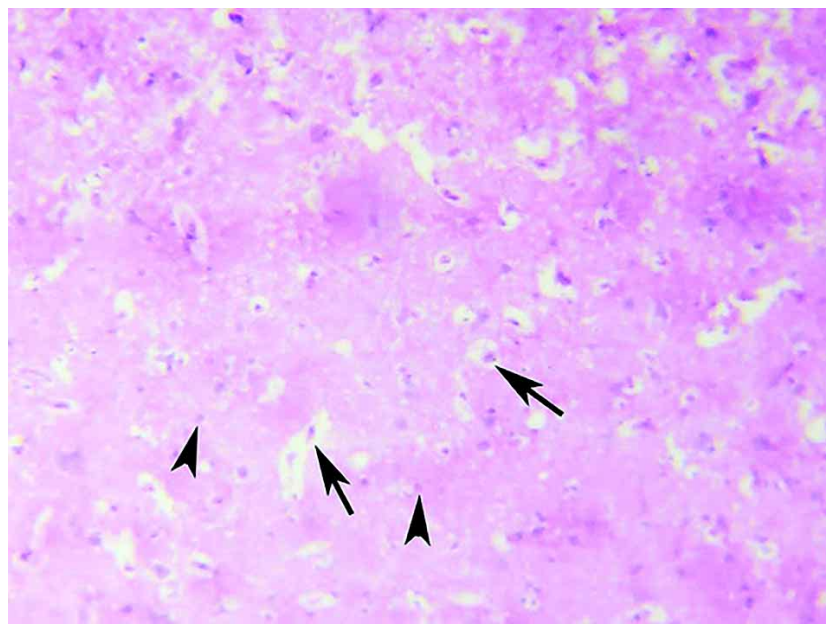

Fig. 7. The cerebral cortex is formed of several ill-defined layers of neurons. Characterized by few small neurons (arrows) supported by neuroglia (arrowheads). H\&E. x 100.

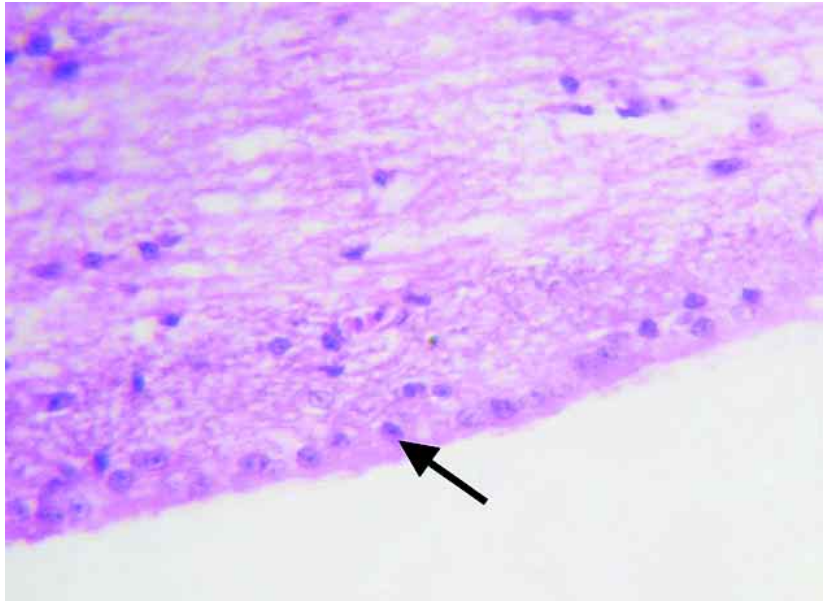

Fig. 8. The 3rd ventricle lined with simple layer of cuboidal ependymal cells (arrow). H\&E. x100.
Optic lobe: The optic nerve was formed from myelinated nerve fibers that merge into the optic lobe (Fig. 10). The optic lobe was formed from medium sized spherical neurons with few neuroglia (Fig. 11). The mesencephalon canal lined with a single layer of cuboidal ependymal cells.

Medulla oblongata: The Medulla oblongata was covered by pia mater of loose connective tissue covered with simple squamous epithelium, vascular supply extended beneath the pia mater (Fig. 12). The cell nuclei of the Medulla oblongata was formed from few multipolar neurons (Figs. 13 and 14), supported by few neuroglia. The fourth ventricle was lined by pseudo stratified columnar ciliated ependymal cells (Fig. $15)$.

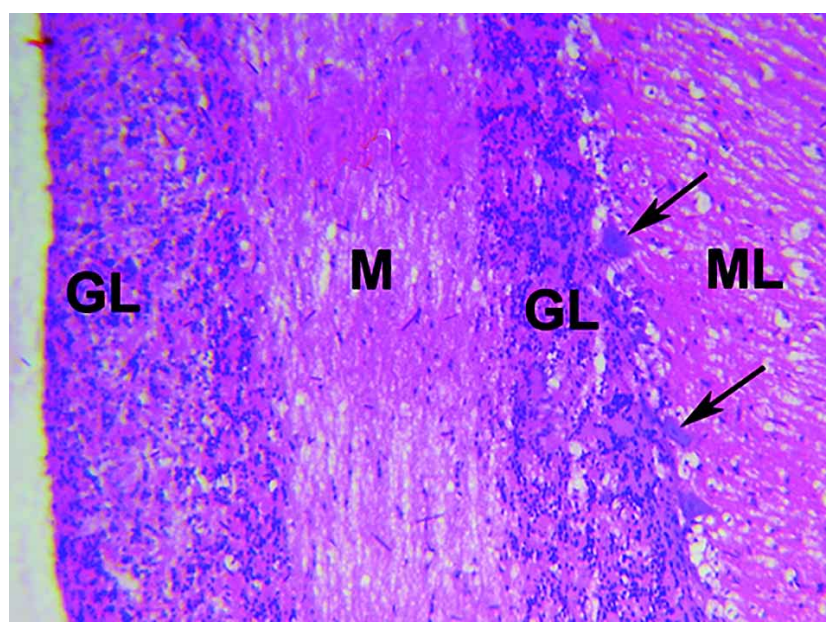

Fig. 9. Cerebellar fold is formed of medulla enclosed with narrow granular layer (GL) of densely packed small spherical neurons. An outer molecular layer (ML) of scattered small neurons. A single layer of Purkinje cells (arrows) with a large cell body is found between these two layers. H\&E. x100.

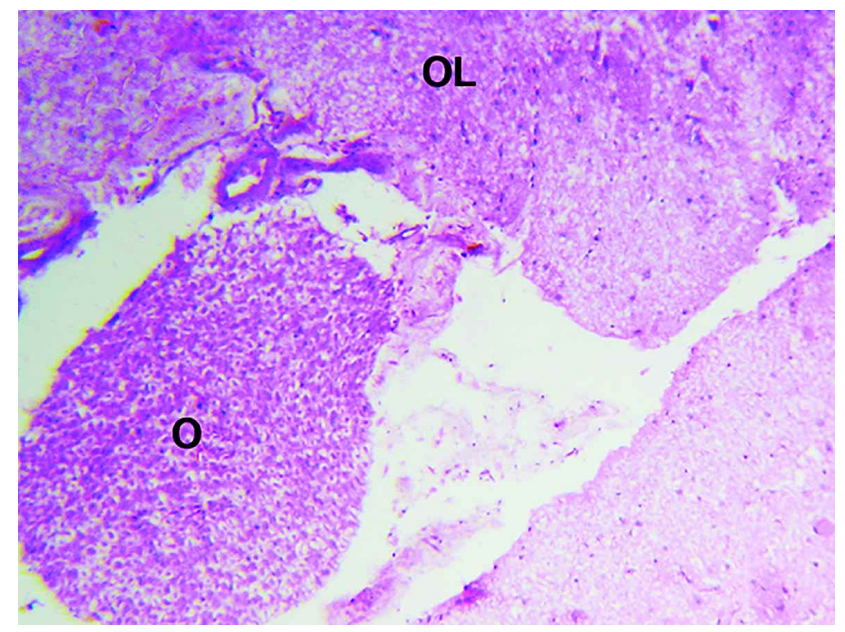

Fig. 10. The optic nerve (o) is formed of myelinated nerve fibers that merge into the optic lobe (OL). H\&E. x32. 


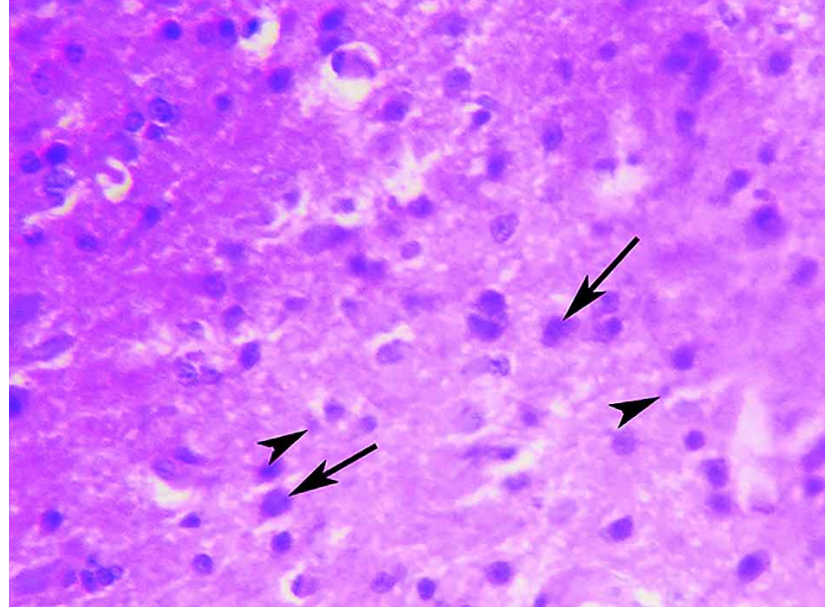

Fig. 11. The optic lobe formed from medium sized neurons (arrows) with few neuroglia (arrowheads). H\&E. x100.

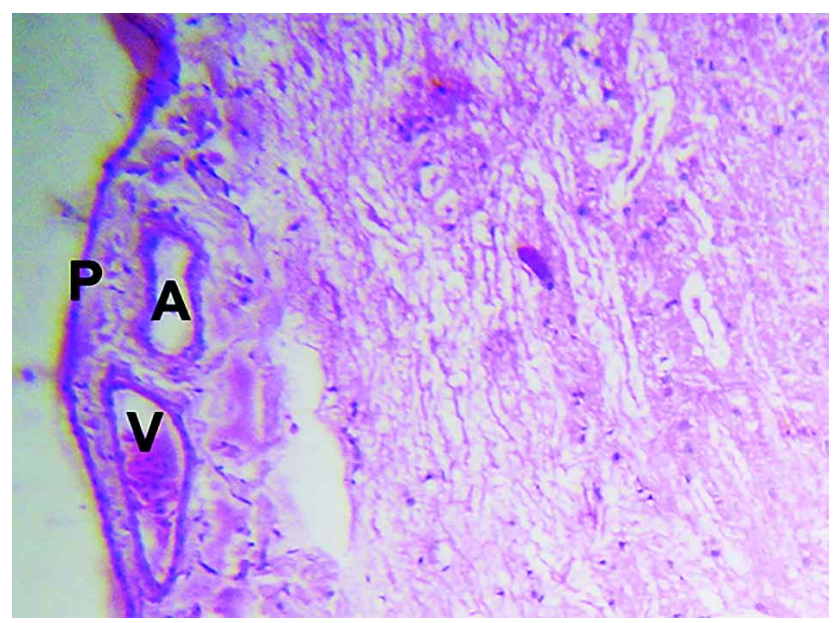

Fig. 12. The medulla oblongata is covered by pia mater $(\mathrm{P})$, vascular supply $(\mathrm{A}=$ artery $\& \mathrm{~V}=$ vein) extended beneath the pia mater. $\mathrm{H} \& \mathrm{E}$. $\mathrm{X} 32$.

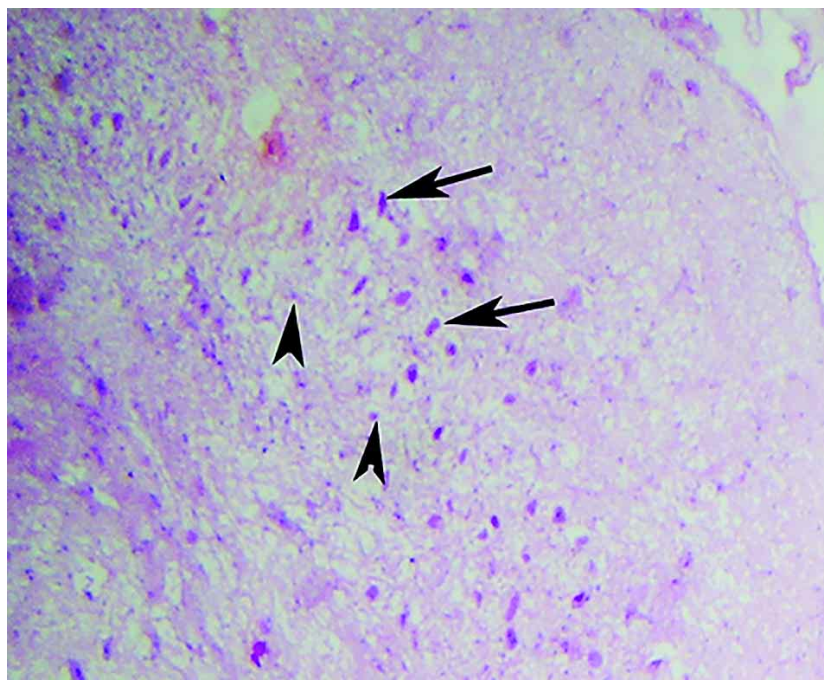

Fig. 13. A cell nucleus of the medulla oblongata is formed from few multipolar neurons (arrows), supported by neuroglia (arrowheads). H\&E. X32.

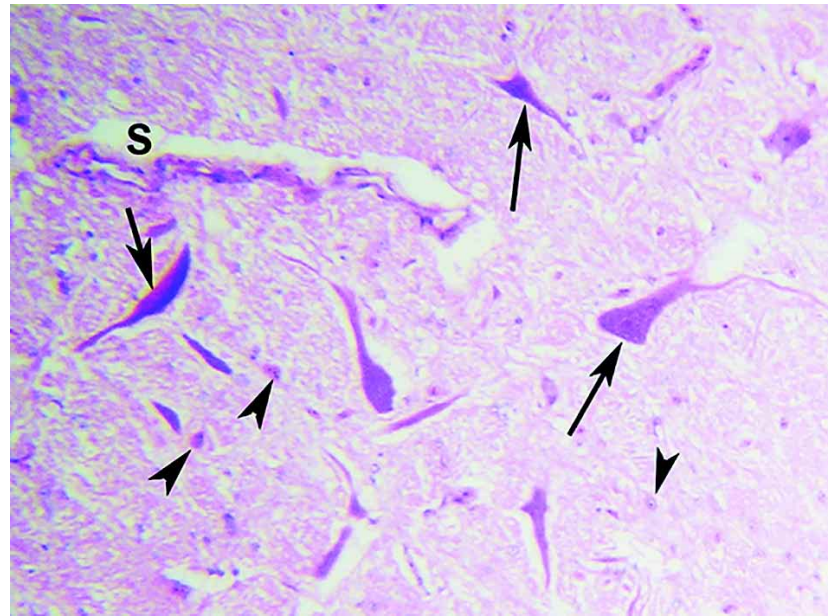

Fig. 14. The multipolar neurons of the medulla oblongata nuclei appeared few and scattered (arrows) the neuroglia were also few (arrowheads). The capillary was enclosed with perivascular space (S). H\&E. X400.

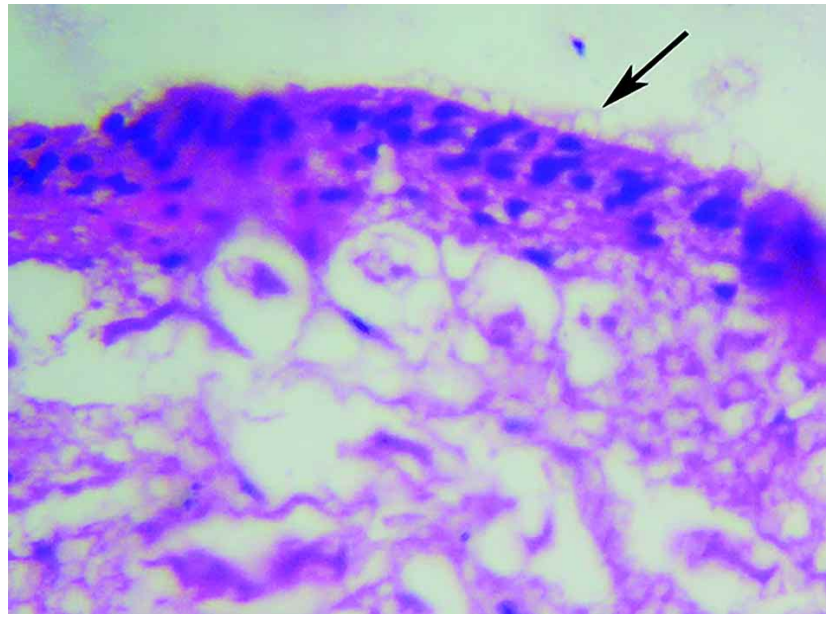

Fig. 15. The fourth ventricle is lined by pseudo stratified columnar ciliated ependymal cells. H\&E. x400

\section{DISCUSSION}

The cerebella of avian species are more developed than of the crawling animals. There are complicated pleats in the superficial gray matter of the cerebellum, which is why it has a larger surface area. The cerebellum executes monitoring, regulating, and correcting by means of a connection with the locomotor system of the brain stem and cerebrum. It receives extra organ information endlessly, at all times, to determine the current condition of every part of the body, such as location, speed of movement, and tension of the muscles (Ruan \& Shou, 1985; Yang, 2002). The cerebellum of the African ostrich protrudes visibly upward and its length is approximately 1.5 times larger than its height. The posterior superior part of the cerebellar vermis 
almost forms an angle of $130^{\circ}$ and the number of transverse sulci of the cerebellar vermis is much larger than that of the domestic fowls. It diverges into more sublobules, which demonstrates that the cerebellar area of the ostrich is accordingly larger and its physiological function is inevitably more complicated. Some experiments show that injuring the cerebellum will severely impact the accuracy of voluntary movement and cause dyskinesia, including the change of muscular tension, disequilibrium, hypomotility or involuntary movement, and so on (Ruan \& Shou). After resecting the cerebellum, the muscles of the cervical area and legs cramp, and the head shakes and twitches irregularly (Sturkie, 1982). African ostriches come from wild deserts with harsh climates and sparse food. Their legs are 1327 $\mathrm{mm}$ long, muscular, and sturdy, so that ostriches can run very fast, with speeds of up to $80-90 \mathrm{~km} / \mathrm{h}$. The physiological functions and life habit of fast running are caused by the ostrich's unique living environment. Legs that can kick backward and tread forward are also used as a weapon to defend against, and fight enemies. These complicated physiological functions are closely related to the characteristics of the ostrich's cerebellar morphology. The nervous system is the most complicated and important synthetic organ system of animals. Its general functions are linked to the enhancement of its characteristic centralization that makes the nervous system form a central part and peripheric part, the central part being more important. The nervous system plays a leading role in controlling vital movements of the animal's organism. It not only adjusts the dynamic balance of every organ system and makes the organism adapt proactively to the surrounding environment, but it is also an information reservoir and the foundation for mental activities (Yang, 1985). The nervous system of the organism shows integrated unity in conformation and function. The magnitude of brain weight or volume is an important yardstick for measuring the development level of animal brains and intellectual ability. The brain of the African ostrich is underdeveloped and there is only a very thin layer of gray matter covering the dorsal and lateral surfaces of the cerebral hemisphere. It depends on the striatum for receiving massive sensory nerve fibers, and the striatum becomes the center of complicated instinctual activity and learning. The olfactory bulbs of the African ostrich are very small. With the underdeveloped olfaction, the olfactory stimulus has little effect on the brain. The underdeveloped brain may lead to the low intelligence of ostrich. Carpolite accumulation in the stomach is a common illness among ostriches (Cong \& Cong, 1998). Ostriches have allotriophagy by nature, and daily observation shows that both adult and young birds always peck a great quantity of carpolite and other things.

Histologically the brain was composed of two major components, the gray matter consists of largely of perkarya of nervous, their dendrites, glia cells, blood vessels, and small amount of nerve fibers that were may be myelinated (Bacha et al., 1990; Batah et al., 2012). The cerebral cortex consisted of six layers molecular layer, external granular layer, external pyramidal layer, internal pyramidal layer and multiform layer (Yokyma et al., 2004; Samuelson, 2007). The current study denoted that all these layers showed the presence of large number of pyramidal cell, satellites cell and blood vessels. The pyramidal cell is characterized by pale large nuclei with Nissals granules in cytoplasm, these findings were similar with (Yokyma et al.; Samuelson; Batah et al.). The cerebral medulla composed of dense bundles of nerve fiber and a unipolor glial cell (Reiner, 2005). The study showed that the cerebellar cortex consists of three layers, external molecular layer, contains pyramidal cells and axon of purkinje cells. The purkinje layer situated between molecular layer and internal granular layer and consists of multipolor purkinje cells these results are similar with (Bunyamin et al., 2001; Batah et al.). The granular layer showed presence of the number of the granular cells which appear dense (Samuelson; Batah et al.).

KARKOURA, A. A.; ALSAFY, M. A. M.; ELGENDY, S. A. A. \& ELDEFRAWY, F. A. Investigación morfológica del cerebro de la avestruz africana (Struthio camelus). Int. J. Morphol., 33(4):1468-1475, 2015.

RESUMEN: El objetivo fue describir las características morfológicas del cerebro de la avestruz africana. El cerebro se estudió macroscópica y microscópicamente, y las mediciones de todas las partes del cerebro fueron registradas. El cerebro tuvo una forma romboidal, con cerebelo grande triangular obtuso con una protuberancia dorsomedial sagital. El bulbo olfatorio era pequeño, con un lóbulo olfativo sin desarrollar. El diencéfalo dio lugar a la glándula pineal, que es una estructura en forma de tubo invertida con un triángulo obtuso en su parte inferior. Un gran quiasma y tracto óptico demostraron ser continuos con los lóbulos ópticos. El cerebelo estaba caracterizado por la vermis central que tenía numerosas fisuras transversales y dos pequeños flóculos laterales en su superficie lateral. La médula oblongada mostró en algunos casos una flexión pontina evidente, en otros ausencia de puentes o la aparición de un cuerpo trapezoide. Los resultados histológicos revelaron que la corteza cerebral está formada de varias capas de neuronas mal definidas. El aspecto más común se caracterizó por unas pequeñas neuronas soportadas por neuroglias. La corteza cerebelosa consistió en tres capas, molecular, de células de Purkinje y granular interna; las células de Purkinje se caracterizaron por un cuerpo celular grande. La medula oblongada estaba cubierta por pia madre de tejido conectivo laxo, revestida por epitelio escamoso simple y un suministro vascular extenso bajo la piamadre. Los núcleos de las células de la médula oblongada se formaron a partir pocas neuronas multipolares, soportados por algunas neuroglias. El cuarto ventrículo estaba revestido un epitelio pseudoestratificado de células ependimarias columnares ciliadas.

PALABRAS CLAVE: Cerebro; Morfología; Avestruz. 


\section{REFERENCES}

Al-Nasser, A.; Al-Khalaifa, K.; Holleman, K. \& Al-Ghalaf, W. Ostrich production in the arid environment of Kuwait. J. Arid Environ., 54(1):219-24, 2003.

Bacha, W. J.; Wood, L. M. \& Bacha, L. M. Color Atlas of Veterinary Histology. Philadelphia, Lea \& Febiger, 1990.

Batah, A. L.; Ghaje, M. S. \& Aziz Sh, N. Anatomical and histological study for the brain of the locally breed chicken (Gallus domesticus). J. Thi-Qar Sci., 3(3):47-53, 2012.

Bunyamin, S.; Hüseyin, A.; Bünyami, U.; Sinan, C.; Sait, B.; Süleyman,K. \& Levent, T. Brain volumes of the lamb, rat and bird do not show hemispheric asymmetry: a stereological study. Image Anal. Stereol., 20:9-13, 2001.

Cong, Z. J. \& Cong, S. Z. Synthesis treatment for sand accumulating in stomach of ostrich chicks. Ostrich Breed. Dev., 12:22-3, 1998.

Dellman, H. D. \& Meclure, R. C. Central Nervous System, Text Book of Histology. Philadephia, Lea ex and Febiger, 1975. pp.150-99.

Mushi, E. Z.; Isa, J. F.; Chabo, R. G. \& Segaise, T. T. Growth rate of ostrich (Struthio camelus) chicks under intensive management in Botswana. Trop. Anim. Health Prod., 30(3):197-203, 1998.

Pal, B.; Chowdhury, S. \& Ghosh, R. K. Comparative anatomical study of the cerebellum of man and fowl. J. Anat. Soc. India, 52(1):32-7, 2003.

Peng, K.; Feng, Y.; Zhang, G.; Liu, H. \& Song, H. Anatomical study of the brain of the African ostrich. Turk. J. Vet. Anim. Sci., 34(3):235-41, 2010.

Reiner, A. A new avian brain nomenclature: Why, how and what. Brain Res. Bull., 66(4-6):317-31, 2005.

Ruan, D. Y. \& Shou, T. D. Neurophysiology. Hefei, China Science and Technology University Press, 1985. pp.139-59.

SAS Institute Inc. SAS/STATâ 9.2 User's Guide. Cary, SAS Institute Inc., 1992.

Samuelson, D. A. Text book of veterinary histology, central nervous system. St. Louis, Saunders, 2007. pp.202-7.

Sturkie, P. D. Poultry Physiology. Beijing, Science Press, 1982. pp.42-5.

Wenqin, C.; Huazhen, L. \& Guanzhong, L. Study on the cytoarchitecture of 5 nuclei of Medulla oblongata in African ostrich (Struthio camelus). Huazhong Nongye Daxue Xuebao, 24(2):185-8, 2005.
Yang, A. F. Vertebrate Zoology. Beijing, Pekin University Press, 1985. pp.259-82.

Yang, X. P. Animal Physiology. Beijing, Higher Education Press, 2002. pp.260-312.

Yokoyama, A.; Yang, L.; Itoh, S.; Mori, K. \& Tanaka, J. Microglia, a potential source of neurons, astrocytes, and oligodendrocytes. Glia, 45(1):96-104, 2004.

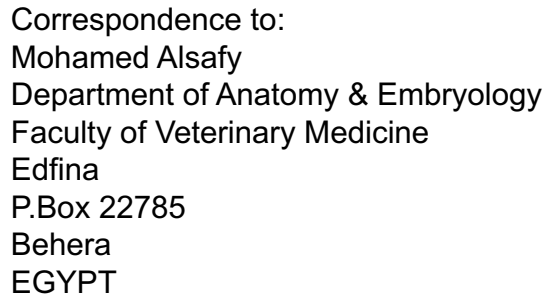

Email: Safy73@yahoo.com

Received: 07-07-2015

Accepted: 25-09-2015 